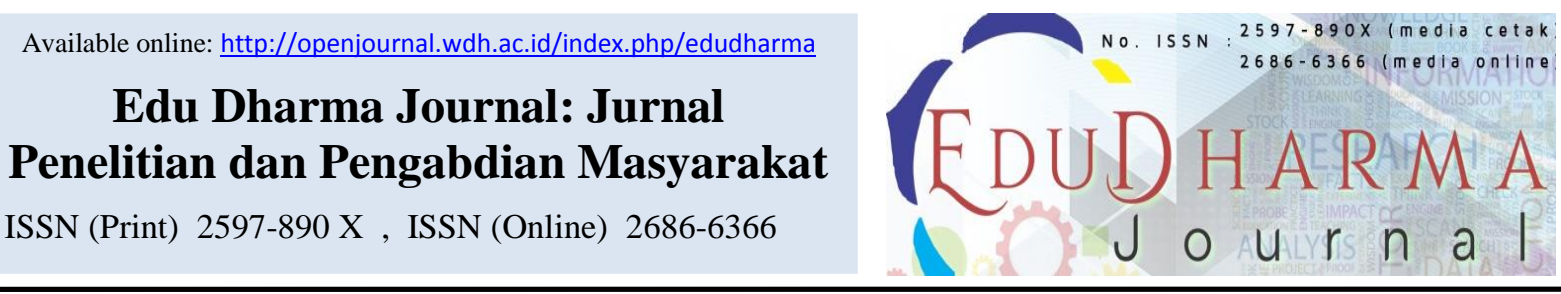

\title{
GAMBARAN FAKTOR-FAKTOR YANG MEMPENGARUHI TINGKAT KEPATUHAN PENDERITA HIV/AIDS TERHADAP PENGOBATAN ANTIRETROVIRAL (ARV) DITINJAU DARI BERBAGAI LITERATUR
}

\author{
Agung Dewantoro $^{1 *}$, Aulia Nadya Rizki Imansari ${ }^{2}$, Ahmad Sayripudin $^{3}$ \\ STIKes Widya Dharma Husada Tangerang, J1,Pajajaran No 1. Kota Tangerang Selatan 15417, Indonesia
}

\begin{tabular}{|c|c|}
\hline ARTICLE INFORMATION & ABSTRACT \\
\hline $\begin{array}{l}\text { *Corresponding Author } \\
\text { Agung Dewantoro } \\
\text { agung_dewantoro89@yahoo.com }\end{array}$ & $\begin{array}{l}\text { Based on WHO data in 2019, there were } 78 \% \text { of new HIV infections in the Asia } \\
\text { Pacific region. In addition, the data on HIV/AIDS cases in Indonesia continues } \\
\text { to increase from year to year, for the last } 11 \text { years HIV cases in Indonesia } \\
\text { peaked in } 2019 \text { as many as } 50,282 \text { cases. Based on this data, the } 5 \text { provinces } \\
\text { with the highest number of HIV cases were East Java }(8,935), \text { DKI Jakarta }\end{array}$ \\
\hline $\begin{array}{l}\text { Keywords: } \\
\text { HIV/AIDS Sufferer_1 } \\
\text { Adherence_2 } \\
\text { Antiretroviral_3 }\end{array}$ & $\begin{array}{l}\text { success of HIV/AIDS treatment with ARV therapy is determined by adherence } \\
\text { to taking ARV drugs and being given long term. The purpose of this study was } \\
\text { to describe the factors that influence the level of adherence of HIV/AIDS } \\
\text { patients to antiretroviral treatment in terms of various literatures. The method } \\
\text { used in this study uses a literature review, namely the purposive sampling } \\
\text { technique. The results of the study based on the level of compliance from the } \\
\text { eight literatures obtained a total of } 831 \text { respondents in the high compliance } \\
\text { category as many as } 469(60.16 \%) \text {, while the category with moderate } \\
\text { compliance obtained as many as } 91 \text { respondents }(30 \%) \text { and in the low } \\
\text { compliance category obtained as many as } 271(36,95 \%) \text {, in addition, there are } \\
\text { factors that influence the level of adherence to antiretroviral treatment such as } \\
\text { the level of knowledge, family support, support from health workers and side } \\
\text { effects. }\end{array}$ \\
\hline $\begin{array}{l}\text { Kata Kunci : } \\
\text { Penderita HIV/AIDS_1 } \\
\text { Kepatuhan_2 } \\
\text { Antiretroviral_3 }\end{array}$ & $\begin{array}{l}\text { A B S T R A K } \\
\text { Berdasarkan data WHO tahun } 2019 \text { terdapat } 78 \% \text { infeksi HIV baru di regional } \\
\text { Asia Pasifik. Selain itu, Untuk data kasus HIV/AIDS di Indonesia terus } \\
\text { meningkat dari tahun ke tahun, selama } 11 \text { tahun terakhir kasus HIV di } \\
\text { Indonesia puncaknya pada tahun } 2019 \text { yaitu sebanyak } 50.282 \text { kasus. } \\
\text { Berdasarkan data tersebut } 5 \text { provinsi dengan jumlah kasus HIV terbanyak yaitu } \\
\text { Jawa Timur (8,935), DKI Jakarta (6.701), Jawa Barat (6.066), Jawa Tengah } \\
\text { (5.630) dan Papua (3.753). Keberhasilan tatalaksana HIV/AIDS dengan terapi } \\
\text { ARV ditentukan oleh kepatuhan minum obat ARV dan diberikan jangka } \\
\text { panjang. Tujuan penelitian ini untuk mengetahui gambaran faktor-faktor yang } \\
\text { mempengaruhi tingkat kepatuhan penderita HIV/AIDS terhadap pengobatan } \\
\text { antiretroviral ditinjau dari berbagai literatur. Metode yang digunakan penelitian } \\
\text { ini menggunakan literatur review yakni dengan teknik purposive sampling. } \\
\text { Hasil penelitian berdasarkan tingkat kepatuhan dari kedelapan literatur } \\
\text { didapatkan sejumlah keseluruhan } 831 \text { responden pada kategori kepatuhan tinggi } \\
\text { sebanyak } 469 \text { (60,16\%), sedangkan kategori dengan kepatuhan sedang }\end{array}$ \\
\hline
\end{tabular}




\begin{tabular}{|l|l|}
\hline & $\begin{array}{l}\text { didapatkan sebanyak 91 responden (30\%) dan pada kategori kepatuhan yang } \\
\text { rendah didapatkan sebanyak 271 (36,95\%), selain itu, didapatkan adanya } \\
\text { faktor-faktor yang berpengaruh pada tingkat kepatuhan terhadap pengobatan } \\
\text { antiretroviral seperti pada faktor tingkat pengetahuan, dukungan keluarga, } \\
\text { dukungan tenaga Kesehatan dan efek samping. }\end{array}$ \\
\hline & \multicolumn{1}{|c|}{ This is an open access article under the CC-BY-NC-SA license } \\
\hline EY NC SA
\end{tabular}




\section{PENDAHULUAN}

Human Immunodeficiency Virus (HIV) adalah sejenis virus yang menginfeksi sel darah putih yang menyebabkan turunnya kekebalan tubuh manusia. Acquired Immune Deficiency Syndrome (AIDS) adalah sekumpulan gejala yang timbul karena turunnya kekebalan tubuh yang disebabkan infeksi oleh HIV. Penderita HIV memerlukan pengobatan dengan Antiretroviral (ARV) untuk menurunkan jumlah virus HIV di dalam tubuh agar tidak masuk ke dalam stadium AIDS, (Pusat Data dan Informasi Kementerian Kesehatan RI, 2020).

Keberhasilan tatalaksana HIV/AIDS dengan terapi ARV ditentukan oleh kepatuhan minum obat ARV. Terapi ARV diberikan jangka panjang dan dikatakan pengobatan yang optimal jika kepatuhan pengobatan mencapai lebih dari 95\% Pasien yang mendapat pengobatan, harus patuh dalam mengkonsumsi obat ARV seumur hidup, tepat waktu dan disiplin.( kemenkes RI,2015)

Berdasarkan data WHO (World Health Organization) tahun 2019, terdapat $78 \%$ infeksi HIV baru di regional Asia Pasifik. Selain itu, Untuk data kasus HIV/AIDS di indonesia terus meningkat dari tahun ke tahun, selam sebelas tahun terakhir kasus HIV di Indonesia mencapai puncaknya pada tahun 2019, yaitu sebanyak 50.282 kasus. Berdasarkan data tersebut lima provinsi dengan jumlah kasus HIV terbanyak adalah Jawa Timur (8.935), DKI Jakarta (6.701), Jawa Barat (6.066), Jawa Tengah (5.630), dan Papua (3.753), dimana pada tahun 2017 kasus HIV terbanyak juga dimiliki oleh kelima provinsi tersebut (Pusat Data dan Informasi Kementerian Kesehatan RI, 2020).

Berkaitan dengan masalah tingkat kepatuhan, terdapat beberapa literatur terkait hasil penelitian seperti yang didapatkan oleh (Jaemi et al., 2020) menunjukan tingkat yang patuh sebanyak 79 responden $(44,1 \%)$, Sedangkan yang tidak patuh didapatkan sebanyak 100 responden $(55,9 \%)$. Kemudian, pada hasil penelitian terbaru yang didapatkan oleh (Yanto \& Nurjanah, 2021) sebanyak 61 responden $(53 \%)$ yang tidak patuh minum obat, serta sebanyak 54 responden (47\%) yang patuh minum obat. Dari data tersebut masih ditemukan permasalahan yakni pada tingkat kepatuhan penderita HIV/AIDS terhadap pengobatan antiretroviral yang masih rendah.

Oleh karena itu, berdasarkan permasalahan diatas, peneliti merasa tertarik untuk melakukan pengkajian 
literatur mengenai gambaran faktor-faktor apa saja yang dapat mempengaruhi tingkat kepatuhan penderita HIV/AIDS terhadap pengobatan antiretroviral (ARV) berdasarkan tinjauan dari berbagai literatur.

\section{METODE}

Penelitian ini menggunakan metode studi literatur. Kriteria inklusi faktor-faktor yang dapat mempengaruhi tingkat kepatuhan penderita HIV/AIDS terhadap pengobatan antiretroviral. Dalam rentang penerbitan 2019-2021 Kriteria Eksklusi terdiri dari tidak terdapat bentuk full text, jurnal tidak dapatdiakses pada web asal jurnal, tidak dapatdi download .

\section{HASIL}

\section{Hasil Penelitian Karakteristik Responden Penderita HIV/AIDS}

\section{a. Usia Responden}

Tabel 1. Usia Responden

\begin{tabular}{|c|c|c|c|c|c|}
\hline No. & Peneliti & $\begin{array}{c}\text { Jumlah } \\
\text { Responden }\end{array}$ & Usia & Jumlah & Persentase \\
\hline \multirow{4}{*}{1.} & \multirow{4}{*}{ (Debby et al., 2019) } & \multirow{4}{*}{198} & 18-25 Tahun & 11 & $5.6 \%$ \\
\hline & & & 26-35 Tahun & 73 & $35,9 \%$ \\
\hline & & & 36-45 Tahun & 84 & $42,4 \%$ \\
\hline & & & 46-55 Tahun & 30 & $15,2 \%$ \\
\hline \multirow{3}{*}{2.} & \multirow{3}{*}{ (Pratiwi et al., 2019) } & \multirow{3}{*}{33} & 26-35 Tahun & 9 & $27.3 \%$ \\
\hline & & & 36-45 Tahun & 19 & $57,6 \%$ \\
\hline & & & 46-55 Tahun & 5 & $15,2 \%$ \\
\hline \multirow{5}{*}{3.} & \multirow{5}{*}{ (Ana et al., 2020) } & \multirow{5}{*}{43} & $<19$ Tahun & 1 & $23 \%$ \\
\hline & & & 20-29 Tahun & 8 & $18,6 \%$ \\
\hline & & & 30-39 Tahun & 24 & $55,8 \%$ \\
\hline & & & 40-49 Tahun & 7 & $16,3 \%$ \\
\hline & & & $>50$ Tahun & 3 & $7 \%$ \\
\hline \multirow{3}{*}{4.} & \multirow{3}{*}{ (Jaemi et al., 2020) } & \multirow{3}{*}{179} & 20-30 Tahun & 98 & $54,7 \%$ \\
\hline & & & 31-40 Tahun & 81 & $45,3 \%$ \\
\hline & & & 41-50 Tahun & 0 & 0 \\
\hline \multirow{3}{*}{5.} & \multirow{3}{*}{ (Erna et al., 2021) } & \multirow{3}{*}{109} & 17-25 Tahun & 24 & $22 \%$ \\
\hline & & & 26-45 Tahun & 70 & $64,2 \%$ \\
\hline & & & 46-65 Tahun & 15 & $13,8 \%$ \\
\hline \multirow{3}{*}{6.} & \multirow{3}{*}{ (Rika \& Linda, 2021) } & \multirow{3}{*}{79} & 15-25 Tahun & 27 & $34,2 \%$ \\
\hline & & & 26-45 Tahun & 47 & $59,5 \%$ \\
\hline & & & 46-65 Tahun & 5 & $6,3 \%$ \\
\hline \multirow[b]{2}{*}{7.} & \multirow{2}{*}{ (Yanto \& Nurjanah, 2021) } & \multirow{2}{*}{115} & 20-25 Tahun & 31 & $26,9 \%$ \\
\hline & & & 26-30 Tahun & 84 & $73,1 \%$ \\
\hline \multirow{6}{*}{8.} & \multirow{6}{*}{ (Dalfian et al., 2021) } & \multirow{6}{*}{75} & 20-25 Tahun & 21 & $28 \%$ \\
\hline & & & 26-31 Tahun & 12 & $16 \%$ \\
\hline & & & 32-37 Tahun & 18 & $24 \%$ \\
\hline & & & 38-43 Tahun & 18 & $24 \%$ \\
\hline & & & 44-49 Tahun & 4 & $5,3 \%$ \\
\hline & & & 50-55 Tahun & 2 & $2,7 \%$ \\
\hline
\end{tabular}



Berdasarkan tabel 1 pada karakteristik usia responden dari ke delapan literatur jurnal penelitian pada rentang penerbitan tahun 2019-2021 didapatkan mayoritas responden berkisar pada usia 20-45 tahun, menurut kelompok Usia, 25-49 tahun atau usia produktif merupakan umur dengan jumlah penderita infeksi HIV terbanyak setiap tahunnya (Pusat Data dan Informasi Kementerian Kesehatan RI, 2020).

\section{b. Jenis Kelamin Responden}

Tabel 2. Jenis Kelamin Responden

\begin{tabular}{|c|c|c|c|c|c|}
\hline No. & Peneliti & $\begin{array}{c}\text { Jumlah } \\
\text { Responden }\end{array}$ & $\begin{array}{c}\text { Jenis } \\
\text { Kelamin }\end{array}$ & Jumlah & Persentase \\
\hline \multirow[t]{2}{*}{1.} & (Debby et al., 2019) & 198 & Laki-laki & 128 & $64,6 \%$ \\
\hline & & & Perempuan & 70 & $35,4 \%$ \\
\hline 2. & (Pratiwi et al., 2019) & & & & \\
\hline \multirow[t]{2}{*}{3.} & (Ana et al., 2020) & 43 & Laki-laki & 26 & $60,5 \%$ \\
\hline & & & Perempuan & 17 & $39,5 \%$ \\
\hline \multirow[t]{2}{*}{4.} & (Jaemi et al., 2020) & 179 & Laki-laki & 130 & $72,6 \%$ \\
\hline & & & Perempuan & 49 & $27,4 \%$ \\
\hline \multirow[t]{2}{*}{5.} & (Erna et al., 2021) & 109 & Laki-laki & 75 & $68,8 \%$ \\
\hline & & & Perempuan & 34 & $31,2 \%$ \\
\hline \multirow[t]{2}{*}{6.} & (Rika \& Linda, 2021) & 79 & Laki-laki & 64 & $81 \%$ \\
\hline & & & Perempuan & 15 & $19 \%$ \\
\hline \multirow[t]{2}{*}{7.} & (Yanto \& Nurjanah, 2021) & 115 & Laki-laki & 71 & $61,7 \%$ \\
\hline & & & Perempuan & 44 & $38,3 \%$ \\
\hline \multirow[t]{3}{*}{8.} & (Dalfian et al., 2021) & 75 & Laki-laki & 59 & $78,7 \%$ \\
\hline & & & Perempuan & 16 & $21,3 \%$ \\
\hline & Total & 798 & & & \\
\hline
\end{tabular}

Berdasarkan tabel 2 pada karakteristik Jenis kelamin responden dari 8 literatur didapatkan 7 literatur yang mencantumkan adanya karakteristik usia responden didapatkan bahwa jumlah lakilaki lebih unggul dibandingkan jenis kelamin perempuan, Terbukti dari data literatur didominasi oleh responden lakilaki dengan masing-masing jumlah responden pada literatur hasil penelitian. Hal ini terbukti jika mengacu berdasarkan data Ditjen P2P yang bersumber dari
Sistem Informasi HIV, AIDS, dan IMS (SIHA) tahun 2019, laporan triwulan 4 menyebutkan bahwa kasus HIV dan AIDS pada laki-laki lebih tinggi dari perempuan. Kasus HIV tahun 2019 sebanyak $64,50 \%$ adalah laki-laki, sedangkan kasus AIDS sebesar 68,60\% pengidapnya adalah laki-laki. Hal ini sejalan dengan hasil laporan HIV berdasarkan jenis kelamin sejak tahun 2008-2019, dimana persentase penderita laki-laki selalu lebih tinggi dari 
perempuan (Pusat Data dan Informasi Kementerian Kesehatan RI, 2020).

\section{c. Tingkat Pendidikan Responden}

Tabel 3. Tingkat Pendidikan Responden

\begin{tabular}{|c|c|c|c|c|c|}
\hline No. & Peneliti & $\begin{array}{c}\text { Jumlah } \\
\text { Responden }\end{array}$ & Kategori & Jumlah & Persentase \\
\hline \multirow[t]{4}{*}{1} & (Debby et al., 2019) & 198 & SD & 3 & $2,5 \%$ \\
\hline & & & SMP & 15 & $6,6 \%$ \\
\hline & & & SMA & 100 & $50,5 \%$ \\
\hline & & & PT & 80 & $40,4 \%$ \\
\hline 2. & (Pratiwi et al., 2019) & & & & \\
\hline \multirow[t]{4}{*}{3.} & (Ana et al., 2020) & 43 & SD & 1 & $2,3 \%$ \\
\hline & & & SMP & 6 & $14 \%$ \\
\hline & & & SMA & 24 & $55,8 \%$ \\
\hline & & & Diploma/Sarjana & 12 & $27,9 \%$ \\
\hline \multirow[t]{4}{*}{4.} & (Jaemi et al., 2020) & 179 & SD & 1 & $0,6 \%$ \\
\hline & & & SMP & 0 & $0 \%$ \\
\hline & & & SMA & 168 & $93,9 \%$ \\
\hline & & & Perguruan Tinggi & 10 & $5,5 \%$ \\
\hline \multirow[t]{4}{*}{5.} & (Erna et al., 2021) & 109 & Tidak sekolah & 0 & $0 \%$ \\
\hline & & & SD-SMP & 23 & $21,1 \%$ \\
\hline & & & SMA & 57 & $52,3 \%$ \\
\hline & & & PT & 29 & $26,6 \%$ \\
\hline \multirow[t]{5}{*}{6.} & (Rika \& Linda, 2021) & 79 & SD & 2 & $2,5 \%$ \\
\hline & & & SMP & 5 & $6,3 \%$ \\
\hline & & & SMA & 59 & $74,7 \%$ \\
\hline & & & Diploma & 2 & $2,5 \%$ \\
\hline & & & Sarjana & 11 & $13,9 \%$ \\
\hline \multirow[t]{3}{*}{7.} & (Yanto \& Nurjanah, 2021) & 115 & Rendah & 79 & $68,7 \%$ \\
\hline & & & Sedang & 30 & $26,1 \%$ \\
\hline & & & Tinggi & 6 & $5,2 \%$ \\
\hline \multirow[t]{2}{*}{8.} & (Dalfian et al., 2021) & 75 & SMP-SMA & 47 & $62,7 \%$ \\
\hline & & & Akademi/Sarjana & 28 & $37,3 \%$ \\
\hline
\end{tabular}

Berdasarkan tabel 3 pada karakteristik tingkat pendidikan responden didapatkan hanya 7 literatur yang mencantumkan adanya karakteristik tersebut didapatkan bahwa mayoritas pada kategori SMA dengan jumlah sebanyak 485 responden, dibawahnya pada kategori perguruan tinggi dengan jumlah terbanyak kedua setelah kategori SMA didapatkan sebanyak
178 responden. Banyaknya penderita HIV pada tingkat Pendidikan tersebut dikarenakan minimnya informasi dan Pendidikan tentang HIV/AIDS. Sehingga pelunya pemerintah melakukan edikasi terkait HIV/AIDS sedini mungkin terutama ppada tingkat SMA dimana remaja memasuki masa kematangan secara seksual. 


\section{d. Jenis Pekerjaan Responden}

Tabel 4. Jenis Pekerjaan Responden

\begin{tabular}{|c|c|c|c|c|c|}
\hline No. & Peneliti & $\begin{array}{c}\text { Jumlah } \\
\text { Responden }\end{array}$ & Kategori & Jumlah & Persentase \\
\hline 1. & (Debby et al., 2019) & & & & \\
\hline 2. & (Pratiwi et al., 2019) & & & & \\
\hline 3. & (Ana et al., 2020) & & & & \\
\hline \multirow[t]{6}{*}{4.} & (Jaemi et al., 2020) & 179 & IRT & 31 & $17,3 \%$ \\
\hline & & & Karyawan Swasta & 59 & $33 \%$ \\
\hline & & & Wiraswasta & 8 & $4,5 \%$ \\
\hline & & & Buruh & 17 & $9,5 \%$ \\
\hline & & & Tidak Bekerja & 11 & $6,1 \%$ \\
\hline & & & PNS/TNI & 53 & $29,6 \%$ \\
\hline \multirow[t]{2}{*}{5.} & (Erna et al., 2021) & 109 & Bekerja & 77 & $70,6 \%$ \\
\hline & & & Tidak bekerja & 32 & $29,4 \%$ \\
\hline \multirow[t]{9}{*}{6.} & (Rika \& Linda, 2021) & 79 & Swasta & 18 & $22,8 \%$ \\
\hline & & & Pegawai & 9 & $11,4 \%$ \\
\hline & & & Wiraswasta & 28 & $35,4 \%$ \\
\hline & & & IRT & 8 & $10,1 \%$ \\
\hline & & & Panti Pijat & 1 & $1,3 \%$ \\
\hline & & & THM & 1 & $1,3 \%$ \\
\hline & & & Sekolah/Kuliah & 9 & $11,4 \%$ \\
\hline & & & Belum bekerja & 3 & $3,8 \%$ \\
\hline & & & Petani/ buruh & 2 & $2,5 \%$ \\
\hline \multirow[t]{2}{*}{7.} & (Yanto \& Nurjanah, 2021) & 115 & Bekerja & 85 & $73,9 \%$ \\
\hline & & & Tidak bekerja & 30 & $26,1 \%$ \\
\hline \multirow[t]{3}{*}{8.} & (Dalfian et al., 2021) & 75 & Bekerja & 50 & $66,7 \%$ \\
\hline & & & Tidak bekerja & 25 & $33,3 \%$ \\
\hline & Total & 557 & & & \\
\hline
\end{tabular}

Berdasarkan tabel 4 pada karakteristik jenis pekerjaan responden dari kedelapan literatur hanya 5 literatur saja yang mencantumkan adanya karakteristik tersebut, pada penelitian oleh (Jaemi et al., 2020) didapatkan mayoritas kategori responden karyawan sebanyak $33 \%$ dari 59 responden, setelah itu responden pada kategori tidak bekerja sebanyak $29,6 \%$ dari 53 responden. Sedangkan pada hasil ke tiga penelitian antara (Erna et al., 2021), (Yanto \& Nurjanah, 2021) dan (Dalfian et al., 2021) didapatkan hasil yang terbanyak terdapat responden kategori bekerja masing-masing sebanyak 77 responden $(70,6 \%), 85$ responden $(73,9 \%)$, dan 50 responden $(66,7 \%)$. Kemudian pada penelitian oleh (Rika \& Linda, 2021) didapatkan responden terbanyak pada kategori wiraswasta sebanyak 28 responden (35,4\%). Jika dikaitkan dengan hasil penelitian tersebut, seseorang yang telah memiliki penghasilan sendiri/bekerja, dan dia belum menikah maka ada 
kecenderungan untuk bebas melakukan perilaku beresiko yang mengakibatkan HIV/AIDS, terlebih mereka berada pada masa reproduksi pada fase tingginya gejolak seksual, jika tidak diimbangi dengan keimanan dan pengetahuan yang cukup maka akan berpotensi untuk melakukan perilaku beresiko seperti perilaku seks bebas, seks bebas tanpa menggunakan kondom, menggunakan narkoba suntik (Jaemi et al., 2020).

\section{Hasil Penelitian Gambaran Tingkat Kepatuhan Penderita HIV/AIDS Terhadap Pengobatan Antiretroviral (ARV)}

Tabel 5. Tingkat Kepatuhan

\begin{tabular}{|c|c|c|c|c|c|c|c|c|}
\hline \multirow{2}{*}{ No. } & \multirow{2}{*}{ Peneliti } & \multirow{2}{*}{$\begin{array}{c}\text { Jumlah } \\
\text { Responden }\end{array}$} & \multicolumn{2}{|c|}{$\begin{array}{c}\text { Kepatuhan } \\
\text { Tinggi }\end{array}$} & \multicolumn{2}{|c|}{$\begin{array}{c}\text { Kepatuhan } \\
\text { Sedang }\end{array}$} & \multicolumn{2}{|c|}{$\begin{array}{c}\text { Kepatuhan } \\
\text { Rendah }\end{array}$} \\
\hline & & & $\mathbf{f}$ & $\%$ & $\mathbf{f}$ & $\%$ & $\mathbf{f}$ & $\%$ \\
\hline 1. & (Debby et al., 2019) & 198 & 98 & $(49,5 \%)$ & 57 & $(28,8 \%)$ & 43 & $(21,7 \%)$ \\
\hline 2. & (Pratiwi et al., 2019) & 33 & 19 & $(57,6 \%)$ & & & 14 & $(42,4 \%)$ \\
\hline 3. & (Ana et al., 2020) & 43 & 27 & $(62,8 \%)$ & & & 16 & $(37,2 \%)$ \\
\hline 4. & (Jaemi et al., 2020) & 179 & 79 & $(44,1 \%)$ & & & $\begin{array}{c}10 \\
0 \\
\end{array}$ & $(55,9 \%)$ \\
\hline 5. & (Erna et al., 2021) & 109 & 75 & $(68,8 \%)$ & 34 & $(31,2 \%)$ & & \\
\hline 6. & (Rika \& Linda, 2021) & 79 & 67 & $(84,8 \%)$ & & & 12 & $(15,2 \%)$ \\
\hline 7. & (Yanto \& Nurjanah, 2021) & 115 & 54 & $(47 \%)$ & & & 61 & $(53 \%)$ \\
\hline 8. & (Dalfian et al., 2021) & 75 & 50 & $(66,7 \%)$ & & & 25 & $(33,3 \%)$ \\
\hline Total & & 831 & 469 & 60,16 & 91 & 30 & $\begin{array}{c}27 \\
1\end{array}$ & 36,95 \\
\hline
\end{tabular}

Berdasarkan tabel 5 didapatkan dengan jumlah responden sebanyak 831 dari kedelapan jurnal penelitian diantaranya sebanyak $(60,16 \%) 469$ responden dengan tingkat kepatuhan tinggi, $\begin{array}{lll}\text { sedangkan } & \text { sebanyak } & (30 \%)\end{array}$ responden dengan tingkat kepatuhan sedang, kemudian sebanyak $(36,95 \%)$
271 responden dengan tingkat kepatuhan rendah. Selain itu, dari semua literatur tersebut, terdapat pula pada hasil penelitian oleh Jaemi et al., 2020 menunjukan adanya (55,9\%) 100 responden termasuk kategori tak patuh, sedangkan sebanyak $(44,1 \%) \quad 79$ responden termasuk kategori patuh. 
Kemudian pada hasil penelitian oleh (Yanto \& Nurjanah, 2021) didapatkan sebanyak (53\%) 61 responden termasuk kategori tak patuh, Sedangkan sebanyak (47\%)54 responden termasuk kategori patuh. Berdasarkan data diatas maka perlunya pemerintah melakukan sosialisasi secara terus menerus untuk meningkatkan kepatuhan pasien HIV/AIDS pada terapi ARV nya agar pengobatan berhasil serta menghuindari timbulnya resistensi obat ARV

\section{Hasil Penelitian Faktor-faktor Yang Mempengaruhi Tingkat Kepatuhan Penderita}

\section{HIV/AIDS Terhadap Pengobatan Antiretroviral}

\section{a. Faktor Tingkat Pengetahuan}

Tabel 6. Faktor Tingkat Pengetahuan

\begin{tabular}{|c|c|c|c|c|c|c|c|}
\hline \multirow[b]{2}{*}{ Peneliti } & \multirow[b]{2}{*}{ Responden } & \multicolumn{2}{|c|}{ Baik } & \multicolumn{2}{|c|}{ Cukup } & \multicolumn{2}{|c|}{ Kurang } \\
\hline & & Patuh & $\begin{array}{c}\text { Tak } \\
\text { patuh }\end{array}$ & Patuh & $\begin{array}{c}\text { Tak } \\
\text { patuh }\end{array}$ & Patuh & $\begin{array}{c}\text { Tak } \\
\text { patuh }\end{array}$ \\
\hline 1. (Debby et al., 2019) & 98 & $\begin{array}{c}78 \\
(55,7 \%)\end{array}$ & & $\begin{array}{c}13 \\
(41,9 \%) \\
\end{array}$ & & $\begin{array}{c}7 \\
(25,9 \%) \\
\end{array}$ & \\
\hline 2. (Pratiwi et al., 2019) & & & & & & & \\
\hline 3. (Ana et al., 2020) & 43 & $\begin{array}{c}15 \\
(51,7 \%)\end{array}$ & $\begin{array}{c}14 \\
(48,3 \%)\end{array}$ & & & $\begin{array}{c}12 \\
(85,7 \%)\end{array}$ & $\begin{array}{c}2 \\
(14,3 \%)\end{array}$ \\
\hline 4. (Jaemi et al., 2020) & 183 & $\begin{array}{c}53 \\
(70,7 \%)\end{array}$ & $\begin{array}{c}26 \\
(29,3 \%)\end{array}$ & & & $26(25 \%)$ & $78(75 \%)$ \\
\hline 5. (Erna et al., 2021) & & & & & & & \\
\hline 6. $\quad$ (Rika \& Linda, 2021) & & & & & & & \\
\hline 7. (Yanto \& Nurjanah, 2021) & 115 & $\begin{array}{c}30 \\
(60 \%)\end{array}$ & $\begin{array}{c}20 \\
(40 \%)\end{array}$ & & & $\begin{array}{c}24 \\
(36,9 \%)\end{array}$ & $\begin{array}{c}41 \\
(63,1 \%)\end{array}$ \\
\hline 8. $\quad$ (Dalfian et al., 2021) & & & & & & & \\
\hline Total & 439 & 176 & 60 & 13 & & 69 & 121 \\
\hline Rata-rata $(\%)$ & & 59,52 & 39,2 & 41,9 & & 43,37 & 50,8 \\
\hline
\end{tabular}

Berdasarkan tabel 6 pada faktor tingkat pengetahuan didapatkan 4 literatur yang menunjukan adanya pengaruh pada tingkat pengetahuan terhadap kepatuhan penderita HIV/AIDS dalam pengobatannya, hasil dari penelitian oleh Debby et al 2019 didapatkan sebanyak $55,7 \%$ dari 78 responden yang menunjukan kategori kepatuhan yang baik serta patuh, Sedangkan sebanyak 41,9\% dari 13 responden menunjukan pada kategori kepatuhan yang cukup serta patuh, kemudian sebanyak $25,9 \%$ dari 7 responden menunjukan pada kategori kepatuhan yang rendah namun tetap patuh. Kemudian pada Penelitian 
oleh Ana et al 2020 didapatkan sebanyak $51,7 \%$ dari 15 responden yang menunjukan kategori kepatuhan yang baik serta patuh, sedangkan sebanyak $85,7 \%$ dari 12 responden menunjukan kategori kepatuhan yang rendah namun tetap patuh. Kemudian pada penelitian oleh Jaemi et al 2020 didapatkan sebanyak $53 \quad(70,7 \%)$ responden menunjukan pada kategori kepatuhan yang baik serta patuh, sedangkan sebanyak 26 (25\%) menunjukan kategori kepatuhan yang rendah namun patuh. Terakhir, pada penelitian oleh Yanto et al 2021 didapatkan sebanyak 30 (60\%) responden menunjukan kategori kepatuhan yang baik serta patuh, sedangkan sebanyak $24 \quad(36, \%)$ menunjukan kategori kepatuhan yang rendah namun tetap patuh. Tingkat pengetahuan terhadap penyakit HIV/AIDS sangat penting dalam meningkatkan kepatuhan pasien pada terapinya. Dalam penelitian didapatkan hasil pasien yang memliki tingkat pengetahuan yang baik terhadap penyakitnya memiliki kepatuhan yang tinggi terhadap terapi ARV nya.

\section{b. Faktor Dukungan Keluarga}

Tabel 7. Faktor Dukungan Keluarga

\begin{tabular}{|c|c|c|c|c|c|c|c|c|}
\hline \multirow{3}{*}{ No. } & \multirow{3}{*}{ Peneliti } & \multirow{3}{*}{$\begin{array}{c}\text { Jumlah } \\
\text { Responden }\end{array}$} & \multicolumn{6}{|c|}{ Tingkat Kepatuhan } \\
\hline & & & \multicolumn{3}{|c|}{ Keluarga Mendukung } & \multicolumn{3}{|c|}{ Keluarga Tak Mendukung } \\
\hline & & & Baik & Cukup & Kurang & Baik & Cukup & Kurang \\
\hline 1. & $\begin{array}{l}\text { (Debby et al., } \\
\text { 2019) }\end{array}$ & 198 & $\begin{array}{c}72 \\
(53,7 \%) \\
\end{array}$ & $\begin{array}{c}39 \\
(29,1 \%)\end{array}$ & $\begin{array}{c}23 \\
(12,9 \%)\end{array}$ & $\begin{array}{c}26 \\
(40,6 \%)\end{array}$ & $\begin{array}{c}18 \\
(28,1 \%)\end{array}$ & $\begin{array}{c}20 \\
(31,3 \%) \\
\end{array}$ \\
\hline \multicolumn{9}{|c|}{ (Pratiwi et al., } \\
\hline 3. & (Ana et al., 2020) & 43 & $\begin{array}{c}21 \\
(75 \%)\end{array}$ & & $\begin{array}{c}7 \\
(25 \%) \\
\end{array}$ & $\begin{array}{c}6 \\
(40 \%) \\
\end{array}$ & & $\begin{array}{c}9 \\
(60 \%) \\
\end{array}$ \\
\hline \multicolumn{9}{|c|}{$\begin{array}{ll}4 . & \text { (Jaemi et al., } \\
& 2020)\end{array}$} \\
\hline 5. & (Erna et al., 2021) & & & & & & & \\
\hline \multicolumn{9}{|l|}{6.} \\
\hline 7. & $\begin{array}{l}\text { (Yanto \& } \\
\text { Nurjanah, 2021) }\end{array}$ & 115 & $\begin{array}{c}43 \\
(56,6 \%) \\
\end{array}$ & & $\begin{array}{c}33 \\
(43,4 \%) \\
\end{array}$ & $\begin{array}{c}11 \\
(28,2 \%)\end{array}$ & & $\begin{array}{c}28 \\
(71,8 \%)\end{array}$ \\
\hline 8. & $\begin{array}{l}\text { (Dalfian et al., } \\
\text { 2021) }\end{array}$ & 75 & $\begin{array}{c}32 \\
(82,1 \%)\end{array}$ & & $\begin{array}{c}7 \\
(17,9 \%)\end{array}$ & $\begin{array}{c}18 \\
(50 \%)\end{array}$ & & $\begin{array}{c}18 \\
(50 \%)\end{array}$ \\
\hline \multicolumn{2}{|c|}{ Total } & 431 & 168 & 39 & 70 & 61 & 18 & 75 \\
\hline \multicolumn{2}{|c|}{ Rata-rata (\%) } & & 66,85 & 29,1 & 24,8 & 39,7 & 28,1 & 53,27 \\
\hline
\end{tabular}

Berdasarkan tabel 7 pada faktor sebanyak 168 responden $(66,85 \%)$ dukungan keluarga didapatkan 4 literatur dengan kepatuhan yang baik setelah yang menunjukan adanya faktor tersebut mendapat dukungan dari 
keluarga,sedangkan 75 responden Keluarga dapat berperan untuk $(53,27 \%)$ dengan kepatuhan yang kurang mengingatkan pasien untuk dikarenakan tidak mendapat dukungan mengkonsumsi obatnya agar jangan keluarga hal ini yang menjadi faktor sampai terlewat dosisinya sehingga berpengaruh terhadap tingkat kepatuhan. pengobatan ARV berjalan sempurna.

\section{c. Faktor Dukungan Tenaga Kesehatan}

Tabel 8. Faktor Dukungan Tenaga Kesehatan

\begin{tabular}{|c|c|c|c|c|c|c|c|c|}
\hline \multirow{3}{*}{ No. } & \multirow{3}{*}{ Peneliti } & \multirow{3}{*}{$\begin{array}{c}\text { Respon } \\
\text { den }\end{array}$} & \multicolumn{6}{|c|}{ Tingkat Kepatuhan } \\
\hline & & & \multicolumn{3}{|c|}{ Mendukung } & \multicolumn{3}{|c|}{ Tidak Mendukung } \\
\hline & & & Baik & Cukup & Kurang & Baik & Cukup & Kurang \\
\hline \multicolumn{9}{|c|}{$\begin{array}{l}\text { (Debby et } \\
\text { al., 2019) }\end{array}$} \\
\hline 2. & $\begin{array}{l}\text { (Pratiwi et } \\
\text { al., 2019) }\end{array}$ & 33 & $\begin{array}{c}14 \\
(77,8 \%)\end{array}$ & & $\begin{array}{c}4 \\
(22,2 \%)\end{array}$ & $\begin{array}{c}5 \\
(33,3 \%)\end{array}$ & & $\begin{array}{c}10 \\
(66,7 \%)\end{array}$ \\
\hline 3. & $\begin{array}{l}\text { (Ana et al., } \\
2020 \text { ) }\end{array}$ & & & & & & & \\
\hline 4. & $\begin{array}{l}\text { (Jaemi et al., } \\
2020 \text { ) }\end{array}$ & & & & & & & \\
\hline 5. & $\begin{array}{l}\text { (Erna et al., } \\
\text { 2021) }\end{array}$ & & & & & & & \\
\hline 6. & $\begin{array}{l}\text { (Rika \& } \\
\text { Linda, 2021) }\end{array}$ & 79 & $\begin{array}{c}67 \\
(84,8 \%)\end{array}$ & & $\begin{array}{c}4 \\
(5,1 \%)\end{array}$ & & & $\begin{array}{c}8 \\
(10,1 \%)\end{array}$ \\
\hline 7. & $\begin{array}{l}\text { (Yanto \& } \\
\text { Nurjanah, } \\
2021 \text { ) }\end{array}$ & & & & & & & \\
\hline 8. & $\begin{array}{l}\text { (Dalfian et } \\
\text { al., 2021) }\end{array}$ & & & & & & & \\
\hline \multicolumn{2}{|l|}{ Total } & 112 & 81 & & 8 & 5 & & 18 \\
\hline \multicolumn{2}{|c|}{ Rata-rata $(\%)$} & & 81,3 & & 13,65 & 33,3 & & 38,4 \\
\hline
\end{tabular}

Berdasarkan tabel 8 pada faktor dukungan dari tenaga kesehatan didapatkan 2 literatur saja yang menunjukan adanya faktor tersebut, sebanyak 81 responden $(81,3 \%)$ dengan kepatuhan yang baik setelah mendapat dukungan tenaga kesehatan, sedangkan 18 responden $(38,4 \%)$ dengan kepatuhan yang kurang dikarenakan tidak mendapat dukungan tenaga kesehatan, hal ini begitu perlu bagi penderita HIV/AIDS terhadap kepatuhan pengobatannya. Dukungan dari tenaga Kesehatan dapat berupa pemberian informasi yang benar dan mengutamakan manfaat postif dari ARV. Serta pentingnya informasi terkait dengan kepatuhan minumobat dan keberhasilan terapi pasien. (Kemenkes,RI 2011). 



\section{d. Faktor Efek Samping Obat}

Tabel 9. Faktor Efek Samping Obat ARV

\begin{tabular}{|c|c|c|c|c|c|c|}
\hline \multirow{3}{*}{ No. } & \multirow{3}{*}{ Peneliti } & \multirow{3}{*}{$\begin{array}{c}\text { Total } \\
\text { Responden }\end{array}$} & \multicolumn{4}{|c|}{ Tingkat Kepatuhan } \\
\hline & & & \multicolumn{2}{|c|}{ Pernah Alami Efek Samping } & \multicolumn{2}{|c|}{$\begin{array}{c}\text { Tak Pernah Alami Efek } \\
\text { Samping }\end{array}$} \\
\hline & & & Patuh & Tak Patuh & Patuh & Tak Patuh \\
\hline 1. & $\begin{array}{l}\text { (Debby et al., } \\
2019 \text { ) }\end{array}$ & & & & & \\
\hline 2. & $\begin{array}{l}\text { (Pratiwi et al., } \\
\text { 2019) }\end{array}$ & & & & & \\
\hline 3. & (Ana et al., 2020) & 43 & $22(78,6 \%)$ & $6(21,4 \%)$ & $5(33,3 \%)$ & $10(66,7 \%)$ \\
\hline 4. & (Jaemi et al., 2020) & & & & & \\
\hline 5. & (Erna et al., 2021) & & & & & \\
\hline 6. & $\begin{array}{l}\text { (Rika \& Linda, } \\
\text { 2021) }\end{array}$ & & & & & \\
\hline 7. & $\begin{array}{l}\text { (Yanto \& } \\
\text { Nurjanah, 2021) }\end{array}$ & & & & & \\
\hline 8. & $\begin{array}{l}\text { (Dalfian et al., } \\
\text { 2021) }\end{array}$ & & & & & \\
\hline \multicolumn{2}{|l|}{ Total } & 43 & 22 & 6 & 5 & 10 \\
\hline \multicolumn{2}{|c|}{ Rata-rata } & & 78,6 & 21,4 & 33,3 & 66,7 \\
\hline
\end{tabular}

Berdasarkan tabel 9 pada faktor berdasarkan efek samping didapatkan hanya 1 literatur saja dengan responden yang pernah mengalami efek samping tetapi patuh yaitu $78.6 \%$ sedangkan yang tidak patuh yaitu $21.4 \%$. Responden yang tidak pernah mengalami efek samping dan tidak patuh yaitu $66.7 \%$ sedangkan yang patuh sebanyak $33.3 \%$. Oleh karena itu, sebelum memulai terapi alangkah baiknya pasien perlu diberikan edukasi terkait efek samping dari setiap obat tanpa membuat pasien takut terhadap pengobatannya, Perlu diingat bahwa tidak semua pasien akan mengalaminya dan bahwa efek samping yang timbul seringnya bisa diatasi dengan baik. Hal ini jauh lebih menguntungkan bila dibandingkan dengan risiko kematian yang pasti akan terjadi bila pasien tidak mendapatkan terapi ARV (Kemenkes,RI 2011). 



\section{KESIMPULAN}

Berdasarkan hasil telaah dari 8 literatur jurnal penelitian didapatkan kesimpulan bahwa, Berdasarkan karakteristik responden didapatkan mayoritas dengan rentang usia pada 20-45 tahun,pada jenis kelamin lakilaki lebih unggul dibandingkan perempuan, dengan tingkat pendidikan mayoritas SMA, dengan jenis pekerjaan responden mayoritas bekerja, Berdasarkan gambaran tingkat kepatuhan dari ke delapan literatur didapatkan total sejumlah 831 responden, sebanyak 469 responden $(60,16 \%)$ pada kepatuhan yang baik, sebanyak $91 \quad(30 \%)$ responden pada kepatuhan yang sedang, dan sebanyak 271 (36,95\%) responden pada kepatuhan yang rendah. Berdasarkan gambaran faktor-faktor yang dapat mempengaruhi tingkat kepatuhan penderita HIV/AIDS terhadap pengobatan antiretroviral didapatkan bahwa adanya faktor dari tingkat pengetahuan, dukungan keluarga, dukungan tenaga Kesehatan serta efek samping obat memiliki pengaruh terhadap keparuhan penderita HIV/AIDS terhadap pengobatan ARV nya .

\section{DAFTAR PUSTAKA}

Agency for Healthcare Research and Quality. (2012). Medication Adherence Interventions: Comparative Effectiveness Closing the Quality Gap: Revisiting the State of the Science.

Ana, J., Gobel, F. A., \& Arman. (2020). Faktor yang Mempengaruhi Kepatuhan Terapi Antiretrovial pada Orang Dengan HIV di Yayasan Peduli Kelompok Dukungan Sebaya Kota Makassar. Window of Public Health Journal, 1(3), 241-249.

Dalfian, Ahmad, \& Dede. (2021). Hubungan Dukungan Keluarga dan Tingkat Pendidikan Pasien Terhadap Kepatuhan Minum Obat AntiretroviralPasien HIV/AIDS di Poli RSUD Dr. Drajat Prawinegara Serang Banten Juni 2021. 1, 8291.

Debby, C., Sianturi, S. R., \& Susilo, W. H. (2019). Faktor-faktor Yang Berhubungan Dengan Kepatuhan Minum Obat ARV Pada Pasien HIV di RSCM Jakarta, Factors Related to Compliance of ARV Medication in HIV Patients at RSCM Jakarta. 10(1), 16-25.

Depkes. Peraturan Menteri Kesehatan Republik Indonesia Nomor 21 Tahun $2013 \quad$ Tentang Penanggulangan HIV Dan AIDS. 2013. 
Erna \& Yudi. (2021). Tingkat Kepatuhan ODHA Minum Obat ARV di Poli VCT Mutu Manikam RSUD Dr, Moch Ansari Saleh Banjarmasin pISSN: 2502-647X; e-ISSN: 25031902. 6(1), 151-160.

Jaemi, J., Waluyo, A., \& Jumaiyah, W. (2020). Kepatuhan Orang dengan HIV/AIDS (ODHA) terhadap Pengobatan Anti Retroviral (ARV). JHeS (Journal of Health Studies), 4(2), 72-84. https://doi.org/10.31101/jhes. 1007

Kemenkes. (2011). Pedoman Nasional Tatalaksana Klinis infeksi HIv dan Terapi antiretroviral.

Kemenkes. (2015). Pedoman Manajemen Program Pencegahan Penularan HIV dan Sifillis dari Ibu ke Anak.

Kemenkes. (2019). Pedoman Nasional Pelayanan Kedokteran Tata Laksana HIV, 8(5), 55.

Kumar \& Robbins S.L., Buku Ajar Patologi (P.awal, P.Braham. Toni \& A.muhammad,Eds), 2014

Permenkes RI. (2013). Peraturan Menteri Kesehatan Republik Indonesia Nomor 21 tahun 2013 tentang Penanggulangan HIV dan AIDS. 2013

\begin{tabular}{crr} 
Permenkes & RI.(2014). & Peraturan \\
Menteri & Kesehatan & Republik \\
Indonesia & Nomor 87 & tentang \\
Pedoman & \multicolumn{2}{c}{ Pengobatan } \\
Antiretroviral tahun 2014 \\
Pratiwi, A., Rohaeti, \& Sukmara, Y.
\end{tabular}
(2019). Dukungan Tenaga

Kesehatan Dengan Kepatuhan

Minum ARV Pada Penderita Hiv

Di Lapas Pemuda Kelas II A

Tangerang. Jurnal Kesehatan, 8(1), 13-26.

Pusat Data dan Informasi Kementerian Kesehatan RI. (2020). Infodatin HIV AIDS. Kementerian Kesehatan RI, 1-8.

Rika, \& Linda. (2021). Hubungan Dukungan Tenaga Kesehatan dengan Kepatuhan Minum Obat Pada ODHA di wilayah kerja Puskesmas Temindung Samarinda. 2(2), 753-760.

Safira N. (2015) Faktor-faktor yang berhubungan dengan kepatuhan penderita hiv/aids mengonsumsi obat antiretroviral (arv) di klinik voluntary counseling and testing (vct) rsup h. adam malik Medan. 2015

Talumewo OC. (2019) Faktor-Faktor Yang Berhubungan Dengan Kepatuhan ODHA Dalam menjalani Terapi ARV Di Puskesmas Tikala Baru Kota Manado Tahun 2019. 2019;8(7):100-107

WHO HIV update, Global Summary Web, World Health Organization, 2019

Yanto, \& Nurjanah, U. (2021). Kepatuhan Minum Obat Anti Retro Viral ( ARV ) Pada Pasien HIV / AIDS. 2(1), 14-22 